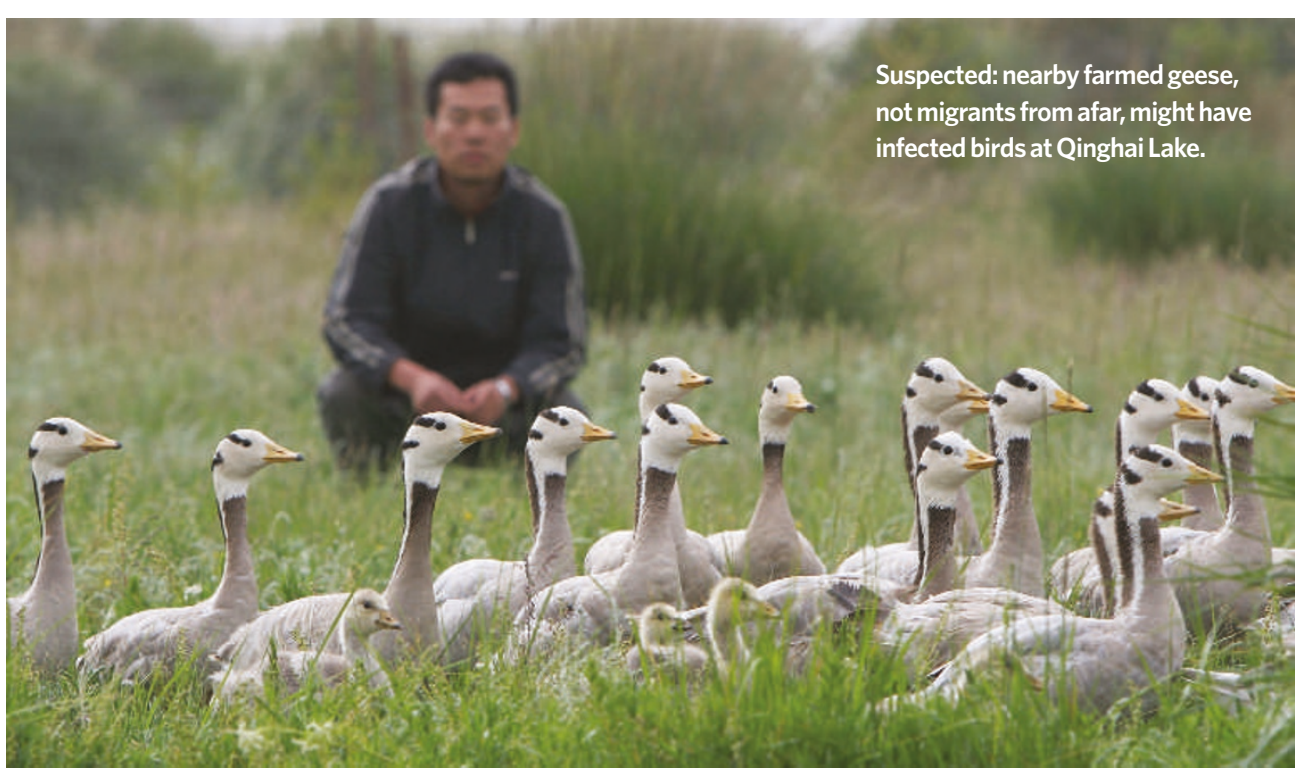

\title{
Blogger reveals China's migratory goose farms near site of flu outbreak
}

The hypothesis that migratory birds are responsible for spreading avian flu over long distances has taken another knock. Last year, an outbreak of the deadly H5N1 strain in thousands of migratory birds at Qinghai Lake in western China provided what seemed the first firm evidence for the idea. Because the lake is so remote, experts assumed infected birds had flown up from southern China.

But it has now emerged that, since 2003 , one of the key migratory species affected, the bar-headed goose, has been artificially reared near the lake. The breeding farms - part of an experimental programme to both domesticate the birds and release them to repopulate wild stocks - raise the possibility that farmed birds were the source of the outbreak.

Roy Wadia, a World Health Organization (WHO) spokesman in Beijing, agrees that, if confirmed, the finding is "important", as changing the breeding practice might help control the infection.
Yi Guan, a virologist at the University of Hong Kong, coauthored a Nature paper last July that suggested migrating birds caused the outbreak (see Nature 436, 191-192; 2005). Guan says he had heard rumours of the programme when he submitted his paper, but couldn't confirm them.

There is no proof that China's breeding programme caused the Qinghai outbreak, but it does raise questions, he says. "The cultivation of bar-headed geese increases "Whether farmed
migrant birds caused
the outbreak or not, the chance for these birds to mix with infected domestic poultry."

Ironically, the breeding programme was revealed by Chinese press agencies reporting on the government's efforts to boost agriculture and the environment in the region ahead of the opening of the Qinghai-Tibet railway in July; the railway is expected to promote tourism and economic growth.

Richard Thomas of BirdLife
International in Cambridge, UK, spotted the press cuttings, and posted English translations to a blog (www.drmartinwilliams.com). Whether farmed migrant birds caused the outbreak or not, it's a "cautionary tale", says Ken Shortridge, a veteran avian-flu researcher in China. He argues that such a programme does not sufficiently take into account the threat of H5N1. The idea that migrating birds didn't carry the virus to

Qinghai after all would fit with other recent evidence. Juan Lubroth, a senior animal-health officer at the UN Food and Agricultural Organization (FAO), says he is now sceptical that migrants can carry the virus over long distances. For example, the current spring migration from Africa to Europe is almost over, with no sign of outbreaks. The FAO has also checked 20,000 wild birds in Africa and found no H5N1.

Declan Butler 